Article

\title{
Climate-Optimized Planting Windows for Cotton in the Lower Mississippi Delta Region
}

\author{
Saseendran S. Anapalli ${ }^{1, *}$, William T. Pettigrew ${ }^{1}$, Krishna N. Reddy ${ }^{1}$, Liwang Ma ${ }^{2}$, \\ Daniel K. Fisher ${ }^{1}$ and Ruixiu Sui ${ }^{1}$ \\ 1 Crop Production Systems Research Unit, USDA-ARS, Stoneville, MS 38776, USA; \\ william.pettigrew@ars.usda.gov (W.T.P.); krishna.reddy@ars.usda.gov (K.N.R.); \\ daniel.fisher@ars.usda.gov (D.K.F.); ruixiu.sui@ars.usda.gov (R.S.) \\ 2 Agricultural Systems Research Unit, USDA-ARS, Fort Collins, CO 80525, USA; liwang.ma@ars.usda.gov \\ * Correspondence: saseendran.anapalli@ars.usda.gov; Tel.: +1-662-686-3755
}

Academic Editor: Philippe Debaeke

Received: 14 July 2016; Accepted: 23 September 2016; Published: 29 September 2016

\begin{abstract}
Unique, variable summer climate of the lower Mississippi (MS) Delta region poses a critical challenge to cotton producers in deciding when to plant for optimized production. Traditional 2-4 year agronomic field trials conducted in this area fail to capture the effects of long-term climate variabilities in the location for developing reliable planting windows for producers. Our objective was to integrate a four-year planting-date field experiment conducted at Stoneville, MS during 2005-2008 with long-term climate data in an agricultural system model and develop optimum planting windows for cotton under both irrigated and rainfed conditions. Weather data collected at this location from 1960 to 2015 and the CSM-CROPGRO-Cotton v4.6 model within the Root Zone Water Quality Model (RZWQM2) were used. The cotton model was able to simulate both the variable planting date and variable water regimes reasonably well: relative errors of seed cotton yield, aboveground biomass, and leaf area index (LAI) were $14 \%, 12 \%$, and $21 \%$ under rainfed conditions and $8 \%, 16 \%$, and $15 \%$ under irrigated conditions, respectively. Planting windows under both rainfed and irrigated conditions extended from mid-March to mid-June: windows from mid-March to the last week of May under rainfed conditions, and from the last week of April to the end of May under irrigated conditions were better suited for optimum yield returns. Within these windows, rainfed cotton tends to lose yield from later plantings, but irrigated cotton benefits; however, irrigation requirements increase as the planting windows advance in time. Irrigated cotton produced about $1000 \mathrm{~kg} \cdot \mathrm{ha}^{-1}$ seed cotton more than rainfed cotton, with irrigation water requirements averaging $15 \mathrm{~cm}$ per season. Under rainfed conditions, there is a $5 \%, 14 \%$, and $27 \%$ chance that the seed cotton production is below 1000, 1500, and $2000 \mathrm{~kg} \cdot \mathrm{ha}^{-1}$, respectively. Information developed in this paper can help MS farmers in decision support for cotton planting.
\end{abstract}

Keywords: agricultural system model; planting window; Mississippi Delta; irrigation; rainfed cropping systems

\section{Introduction}

Historically, fluctuations in production costs, commodity market prices, insect infestations, and weather have mostly controlled the area of cotton planted in the state of Mississippi (MS), and, on an annual average basis, about half a million hectares of this region are planted with this crop. Adequate soil moisture and topsoil $(5 \mathrm{~cm})$ temperature above $20{ }^{\circ} \mathrm{C}$ (on average) at and 10 days following planting cotton are considered ideal for establishing a uniform plant stand, and these conditions normally occur by April in the lower MS Delta region (Riley et al., 1964 [1,2]). While these are ideal conditions for establishing a uniform plant stand, subsequent crop growth and harvested seed cotton 
at the end of the season depend on many other factors, such as incidences and control of weeds, insects, diseases, and water availability either through rainfall or irrigation. Notwithstanding, the net return to the farmers depends on additional factors such as cotton fiber quality, seed composition, and market prices at the time of harvest (Bridge et al., 1971 [3]; Pettigrew and Dowd, 2011 [4]). Therefore, from a producer's point of view, a planting decision for optimum production and economic return should take all of these factors into account. Considerable research efforts have been invested into conducting field trials to understand and develop optimum planting dates for maximizing cotton production and returns in the MS Delta region. Wrather et al. (2008) [5] investigated effects of five planting dates from 22 April to 20 May on yield and fiber quality; Adams et al. (2013) [6] explored mid-April to early May planting-date effects on maturity and yield in cotton; and Pettigrew et al. (2009) [7], Pettigrew and Meredith (2009) [8], and Pettigrew and Dowd (2011) [4] investigated effects of varying planting dates on cotton growth and lint production, cotton seed composition, lint yield components, and fiber quality. In general, in all of these experiments, cotton was planted on three to four different dates between April and May and was repeated over three to four crop seasons. High variability in precipitation and temperatures experienced in the MS Delta across years confounded research outcomes to the extent that no definite patterns in cotton yield return appeared to emerge from these experiments for transferring the technology_or recommending definite planting windows and their associated risks - to producers for adoption. In a two-year study with four plantings between April and May, Berry et al. (2008) [9] recommended early plantings for cotton in the MS Delta region to avoid yield losses from tarnished plant bug attacks. Pettigrew et al. (2009) [7] planted cotton in the first week of April and first week of May for three years (2002-2005), and reported substantial (22\%) increase in lint cotton yields from early plantings in one year but not in the other years. Pettigrew (2002) [10], (2010) [11] reported yield increases in four out of five years from a first-week-of-April planting compared to a first-week-of-May planting. In a four-year study from 2005 to 2008, Pettigrew and Dowd (2010) [12] observed a 35\% decrease in lint yield from early plantings (first week of April) compared to a late planting (first week of May) under rainfed conditions, but in 2006 and 2007, early planting increased lint yield by $13 \%$ under irrigated, but not rainfed, conditions.

One of the main factors contributing to the vacillating, and at times conflicting, outcomes from those experiments is the climate variability (precipitation amount and timing and air temperature) the crops are subjected to across the crop seasons. A solution to the problem would be to derive planting-date recommendations based on data collected-with frequent plantings spread uniformly across crop growth seasons over the long-term (30 years or more) to account for variations in precipitation and other climatic variables-at a location for deriving long-term averaged optimum planting dates for adoption. Such long-term experiments, obviously, are time-consuming and so not suited for deriving timely solutions keeping pace with the changes in technology in the cotton production scenario in the region. In this context, state-of-the-science agricultural system models provide a systems approach and a fast, scientifically sound method for extrapolating short-term field trials outside of the experimental period and climate by integrating crop simulation models with short-term field experiments and long-term weather data to account for long-term climate variability at the location (Hoogenboom et al., 1991 [13]; Ahuja et al., 2000, 2014a,b [14-16]; Saseendran et al., 2005 [17]; Garciay Garcia et al., 2010 [18]; Paz et al., 2012 [19]). However, process-oriented system models, such as Root Zone Water Quality Model (RZWQM2) and the Decision Support Systems for Agrotechnology Transfer (DSSAT) models, need to undergo a thorough calibration and validation process for ascertaining their abilities in reproducing the relevant crop responses in the climate and soil of the location for application (Jones et al., 2003 [20], Ahuja et al., 2014a,b [15,16]). In this context, the CSM-CROPGRO-cotton model available in the DSSAT cropping system simulation package was used extensively for simulating cotton for irrigation water management in the humid climate of southeastern USA (Guerra et al., 2007 [21]; Garcia y Garcia et al., 2010 [18]). However, studies on using the model for simulations of cotton in the humid MS Delta region are lacking. The CSM-CROPGRO-cotton model simulates growth and development of a cotton crop on a daily basis; however, photosynthesis 
is simulated on an hourly basis based on canopy light interception and accounting for growth and maintenance respiration (Boote and Pickering, 1994 [22]). The assimilated dry-matter is partitioned into roots, stems, leaves, bolls, and seeds. Growth stages of seedling emergence, first leaf, first flower, first seed, first cracked boll, and $90 \%$ open boll are simulated from a photothermal time concept function of air temperature and photoperiod. The yield outputs of the model include separate estimates of boll and seed cotton mass.

On an annual basis over the long term, the rainfall (precipitation received in the subtropical climate is mostly in the form of rainfall) received over the MS Delta region averages around $1300 \mathrm{~mm}$, with about 30\% (390 $\mathrm{mm}$ ) received during the core crop-growing period from May to August. The rainfall received is also characterized by high intraseasonal variabilities of both amounts and temporal distribution (Kebede et al., 2014 [23]). For reliable crop returns, farmers depend on irrigations to cover precipitation deficiencies. As such, finding enough water supplies to meet crop demands is one of the primary crop production concerns for farmers in this region. Apparently, the major source of this irrigation water comes by pumping from the Mississippi River Valley alluvial aquifer underlying the MS Delta region (Clark et al., 2011 [24]). Thus, unsustainable withdrawal of water from this shallow aquifer is leading to its fast depletion, posing concerns for continued irrigation water supply for sustaining agriculture in the region. The objectives of this study were to (1) test the CSM-CROPGRO-cotton model v4.6 within the RZWQM2 model for simulations of cotton growth in the humid climate of the MS Delta; and (2) integrate the model with long-term climate data and determine averaged planting windows for optimum production under both rainfed and irrigated conditions in the region.

\section{Materials and Methods}

\subsection{RZWQM2 Model}

The RZWQM2 is a cropping system model that simulates the effects of water (irrigation and precipitation), soil (tillage, crop residue, and fertilizers), and crop management alternatives (crop species and cultivars; planting date, depth, and density; pesticides and fertilizer application amounts; and irrigation amounts and scheduling) on crop production, water quantity and quality, and air (carbon dioxide, nitrous oxide, and methane production) and soil (nitrogen and pesticides) quality (Ahuja et al., 2000 [14]; Ma et al., 2009 [25]). Several studies have tested the model on field research conducted in the Great Plains and Mississippi and extended the results for managing dryland and irrigated cropping systems across climates and soils (for example, Ma et al., 2003 [26]; Saseendran et al., 2005 [17], 2008 [27], 2009 [28]). Saseendran et al. (2014) [29] modified the water stress factor for processes related to photosynthesis (SURFAC) in RZWQM2 using the daily potential root water uptake (TRWUP) calculated by the approach of Nimah and Hanks (1973) [30] and accounted for stress caused by additional heating of the canopy from unused energy of potential evaporation. The CSM-CROPGRO-cotton growth model version 4.6 is available within RZWQM2 for simulations of the crop (Ma et al., 2006 [31], 2009 [25]; Hoogenboom et al., 1991 [13], 2012 [32]; Jones et al., 2003 [20,33]).

RZWQM2 is a daily time-step model; the minimum weather variables needed for simulations representing the experimental location are daily solar irradiance, maximum and minimum air temperature, wind speed, relative humidity, and precipitation. Model inputs include soil physical properties (soil profile depth and horizons/layers, soil texture, bulk density, and organic matter content) and hydraulic properties (water retention curves and saturated hydraulic conductivity of each soil horizon represented by Brooks and Corey equations), crop and soil management information (tillage dates and methods; planting date, density, depth, and row spacing; dates and amounts of irrigation; and amount and type of fertilizer applications), and soil initial conditions (soil water, nitrogen $(\mathrm{N})$, and carbon content of soil layers at the start of the simulation).

The daily potential evaporation (PE) and potential transpiration (PT) are calculated from daily weather variables (air temperature, solar radiation, relative humidity, and wind speed) and crop-soil characteristics using the extended Shuttleworth-Wallace (S-W) approach, which is an extension of the 
S-W approach for partial crop canopy-soil cover to a complete range of partial soil-crop canopy-residue conditions (Shuttleworth and Wallace, 1985 [34]). The potential evapotranspiration (PET) is obtained by summing the PE and PT estimates during a given time interval. The PT and PE computed set the upper limits for actual transpiration (AT) and actual evaporation (AE), respectively, in RZWQM2. The vertical soil water movement (infiltration) during rainfalls or irrigation is simulated by the Green and Ampt (1911) [35] approach, and by the Richards equation (Ahuja et al., 2000 [14]) between these events. The crop water uptake is estimated by the Nimah and Hanks (1973 [30]) approach. The soil evaporation is calculated by the Richards equation of soil water movement, with the flux of PE as the initial upper boundary condition until the soil water pressure head at the surface equals $-1500 \mathrm{kPa}$, which is then maintained as the constant head boundary. The crop growth and water stress effects utilize the widely tested modules from the DSSAT cropping model (Jones et al., 2003 [20]).

In the order of importance, experimental data needed for calibrating the model for simulating a cotton variety are phenology (flowering and physiological maturity) dates, seed cotton yield and biomass at maturity, crop biomass and leaf area index (LAI) at different growth stages, rooting depth and distribution in the soil profile, and soil water content measurements. To simulate a specific cotton cultivar, the CSM-CROPGRO-cotton model requires 18 cultivar parameters (Jones et al., 2003 [20]). Simulating cropping systems require careful iterative calibration of the soil water component, followed by the $\mathrm{N}$ component, and finally the plant growth component. In this study, RZWQM2 was calibrated manually following the comprehensive procedure laid out by Ma et al. (2011 [36]) (Table 1).

Table 1. Calibrated cultivar parameters for simulating cotton c.v. ST5599BR using the CSM-CROPGRO-cotton model v4.6.

\begin{tabular}{|c|c|c|}
\hline Parameters & Definitions & Values \\
\hline CSDL & $\begin{array}{c}\text { Critical Short Day Length below which reproductive development progresses with no day length } \\
\text { effect (for short day plants) (hour) }\end{array}$ & 23.0 \\
\hline PPSEN & $\begin{array}{c}\text { Slope of the relative response of development to photoperiod with time (positive for short day } \\
\text { plants) (1/hour) }\end{array}$ & 0.01 \\
\hline EM-FL & Time between plant emergence and flower appearance (R1)(photothermal days) & 41.0 \\
\hline FL-SH & Time between first flower and first pod (R3) (photothermal days) & 11.0 \\
\hline FL-SD & Time between first flower and first seed (R5) (photothermal days) & 17.0 \\
\hline SD-PM & Time between first seed (R5) and physiological maturity (R7) (photothermal days) & 40.0 \\
\hline FL-LF & Time between first flower (R1) and end of leaf expansion (photothermal days) & 65.0 \\
\hline LFMAX & Maximum leaf photosynthesis rate at $30 \mathrm{C}, 350 \mathrm{vpm} \mathrm{CO}_{2}$, and high light $\left(\mathrm{mg} \mathrm{CO}_{2} / \mathrm{m}^{2} \mathrm{~s}\right)$ & 1.4 \\
\hline SLAVR & Specific leaf area of cultivar under standard growth conditions $\left(\mathrm{cm}^{2} / \mathrm{g}\right)$ & 170.0 \\
\hline SIZLF & Maximum size of full leaf (three leaflets) $\left(\mathrm{cm}^{2}\right)$ & 200.0 \\
\hline XFRT & Maximum fraction of daily growth that is partitioned to seed + shell & 0.50 \\
\hline WTPSD & Maximum weight per seed (g) & 0.15 \\
\hline SFDUR & Seed filling duration for pod cohort at standard growth conditions (photothermal days) & 35.0 \\
\hline SDPDV & Average seed per pod under standard growing conditions (\#/pod) & 20.0 \\
\hline PODUR & Time required for cultivar to reach final pod load under optimal conditions (photothermal days) & 8.0 \\
\hline
\end{tabular}

\subsection{Field Experiments}

The experiments for calibration and evaluation of the model for simulating cotton growth were conducted in a Dubbs silt loam soil (fine-silty, mixed, active, thermic Typic Hapludalfs) at Stoneville, Mississippi $\left(33^{\circ} 42^{\prime} \mathrm{N}, 90^{\circ} 92^{\prime} \mathrm{W}, 32 \mathrm{~m}\right.$ amsl) located in the MS Delta region of the state of Mississippi during the years 2005-2008 (Pettigrew and Dowd, 2011 [4]). Cotton variety ST5599BR was grown under both irrigated and rainfed (crop whose water supply is met only from natural rainfall) conditions following planting on two planting dates: (1) early plantings (EP) occurring in the last week of March or first week of April (4 April 2005, 30 March 2006, 2 April 2007, and 31 March 2008); and (2) normal plantings (NP) occurring typically in the first week of May or last week of April (2 May 2005, 2 May 2006, 27 April 2007, and 6 May 2008). The irrigated treatments were furrow irrigated, with approximately $2.54 \mathrm{~cm}$ of water applied at each irrigation event. One irrigation 
application occurred in 2005, three applications in 2006, two applications in 2007, and four applications in 2008. The experimental design consisted of a randomized complete block with irrigation replications in three blocks. Nitrogen rates were $120 \mathrm{~kg} \cdot \mathrm{ha}^{-1}$ in all the treatments. Each plot measured four rows width and $18.3 \mathrm{~m}$ in length, with cotton planted on a $100 \mathrm{~cm}$ row spacing. After defoliation of the crop, the two interior rows were mechanically harvested from each plot, avoiding the ends of the rows, for cotton seed yield data. LAI and biomass measurements were through destructive sampling; as such, to avoid losing too many plants, we collected these data only once they reached the flowering stage.

Long-term weather data for this location were obtained from the Delta Research and Extension Center, Mississippi State University, weather station located at Stoneville [2]. There were only field measurements of soil textural properties in the experiment: sand $=10 \%$, silt $=55 \%$, clay $=35 \%$, bulk density $=1.42 \mathrm{~g} \cdot \mathrm{cm}^{-3}$, uniform up to a depth of $120 \mathrm{~cm}$. Therefore, soil hydraulic properties were obtained from the RZWQM2 model database for a silt-loam soil: soil water content (SWC) at field saturation $=0.471 \mathrm{~cm}^{3} \cdot \mathrm{cm}^{-3}$, drained upper limit for SWC $=0.343 \mathrm{~cm}^{3} \cdot \mathrm{cm}^{-3}$, drained lower limit for SWC $=0.210 \mathrm{~cm}^{3} \cdot \mathrm{cm}^{-3}$, and pore size distribution index obtained by fitting the Brooks-Corey equation for obtaining the soil water retention curve $=0.151$ (Brooks and Corey, 1964 [37]).

\subsection{Model Application: Determining Optimum Planting Window}

The calibrated and validated model was integrated with a 56 year weather data set, consisting of rainfall, maximum and minimum temperature, solar radiation, and wind speed, collected at the Stoneville location for the period 1960-2015. Simulated planting dates were set at weekly intervals from 1 March to 12 July each year, and simulations started with the initial conditions on 1 January of every year. The 56 year weather data were input to the simulation model to simulate seed cotton yield corresponding to each planting date, and probabilities of achieving average even seed cotton yields (3000 kg.ha ${ }^{-1}$ under irrigated and $2000 \mathrm{~kg} \cdot \mathrm{ha}^{-1}$ under rainfed conditions) were computed for each planting date. These expected yields under rainfed and irrigated conditions were determined after analyzing the long-term yield trends for the location.

\subsection{Statistics for Model Calibration and Evaluations}

Three statistics were used to evaluate the simulation accuracies: (i) root mean squared error (RMSE), defined in Equation (1), between simulated and observed values; (ii) relative RMSE (relative error; RRMSE), which varies between $0 \%$ and 100\%, defined in Equation (2); and (iii) the mean error between measured and simulated values (ME), defined in Equation (3).

$$
\begin{gathered}
R M S E=\sqrt{\frac{1}{n} \sum_{i=1}^{n}(P i-O i)^{2}} \\
R R M S E=\frac{R M S E}{O_{a v g}} \\
M E=\frac{1}{n} \sum(P i-O i)
\end{gathered}
$$

where, $O_{\mathrm{i}}$ is the $i$ th observed value, $P_{\mathrm{i}}$ is the $i$ th simulated value, $O_{a v g}$ is the average of the observed values, and $n$ is the number of data pairs.

\section{Results and Discussion}

\subsection{Climate of the Location}

During 2005, 2006, 2007, and 2008 experiments, 42\%, 27\%, 46\%, and 36\%, respectively, of the annual rainfall occurred during May-August (Table 2). Highest maximum temperatures observed at the location during the experiments were $39.4^{\circ} \mathrm{C}$ in $2005,38.9^{\circ} \mathrm{C}$ in $2006,39.4{ }^{\circ} \mathrm{C}$ in 2007 , and $38.9^{\circ} \mathrm{C}$ in 2008, with all events occurring in August (Figure 1). Also, August is the hottest month 
limiting cotton growth in the region, with maximum temperatures above $34{ }^{\circ} \mathrm{C}$, the upper optimum temperature for cotton growth, consecutively for 18, 24, 30, and 23 days in August in 2005, 2006, 2007, and 2008, respectively. Minimum temperatures remained above $10^{\circ} \mathrm{C}$, the lower minimum optimum temperature for cotton growth, during each of the entire crop seasons.

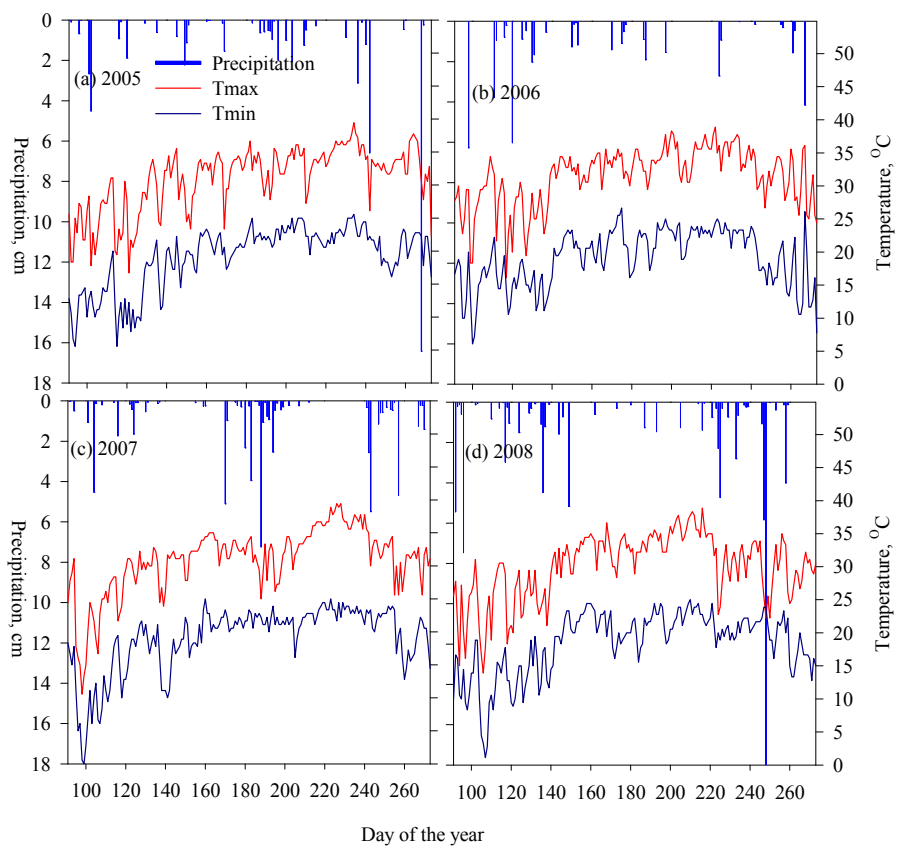

Figure 1. Weather recorded at Stoneville, Mississippi during the crop seasons (April-September) of 2005 (a), 2006 (b), 2007 (c), and 2008 (d): maximum and minimum temperature and precipitation.

Table 2. Cotton growing season weather in $2005,2006,2007$, and 2008: monthly mean daily minimum (Tmin) and maximum temperature (Tmax), and monthly total precipitation.

\begin{tabular}{|c|c|c|c|}
\hline & $\operatorname{Tmin}\left({ }^{\circ} \mathrm{C}\right)$ & $\operatorname{Tmax}\left({ }^{\circ} \mathrm{C}\right)$ & Precipitation $(\mathrm{cm})$ \\
\hline \multicolumn{4}{|c|}{2005} \\
\hline April & 13.4 & 25.3 & 10.8 \\
\hline May & 14.4 & 25.3 & 5.1 \\
\hline June & 14.8 & 25.2 & 1.8 \\
\hline July & 13.2 & 25.0 & 10.2 \\
\hline August & 12.9 & 24.8 & 12.2 \\
\hline September & 12.7 & 24.6 & 17.2 \\
\hline \multicolumn{4}{|c|}{2006} \\
\hline April & 13.8 & 25.6 & 18.0 \\
\hline May & 13.7 & 25.6 & 7.0 \\
\hline June & 13.6 & 25.5 & 3.2 \\
\hline July & 13.3 & 25.2 & 4.3 \\
\hline August & 13.0 & 24.9 & 3.8 \\
\hline September & 12.6 & 24.4 & 6.6 \\
\hline \multicolumn{4}{|c|}{2007} \\
\hline April & 14.6 & 26.3 & 8.2 \\
\hline May & 14.8 & 26.4 & 3.0 \\
\hline June & 14.6 & 26.2 & 9.5 \\
\hline July & 14.2 & 25.8 & 18.6 \\
\hline August & 13.7 & 25.4 & 8.4 \\
\hline September & 13.0 & 24.6 & 11.3 \\
\hline \multicolumn{4}{|c|}{2008} \\
\hline April & 14.3 & 29.1 & 14.0 \\
\hline May & 16.3 & 31.5 & 16.8 \\
\hline June & 17.6 & 32.7 & 1.0 \\
\hline July & 14.5 & 28.9 & 4.0 \\
\hline August & 13.5 & 26.1 & 14.6 \\
\hline September & 13.1 & 24.0 & 28.6 \\
\hline
\end{tabular}




\subsection{Calibration and Validation of the Model}

No information was available for the cultivar parameters required for simulating growth and development of cotton variety ST5599BR using the CSM-CROPGRO-cotton model. Therefore, those parameters were calibrated by manually adjusting them following the Ma et al. (2011 [36]) agricultural system model calibration and parameterization protocols, using the measured cotton growth characteristics (flowering and physiological maturity dates, LAI, aboveground biomass, and seed cotton yield) in the irrigated, normal planting date experiment in 2008 (Table 1). Data was collected from both irrigated and rainfed experiments in the early planting date experiment in 2008, and both the early and normal planting date experiments in 2005, 2006, and 2007 were used for validation of the model. However, as the simulation results did not differ noticeably between the calibration and validation data, all four years of simulation results are discussed together.

Overall, the cotton LAI simulations, under both rainfed and irrigated conditions, were in reasonable agreement with the field measurements, as reflected in the equal distribution of plotted points around the 1:1 line in Figure 2. However, simulated LAI values of the rainfed crop were less accurate compared to the irrigated crop LAI simulations. This behavior of the model appears to be an artifact of the higher plant-to-plant variability in the rainfed experiment and consequent greater error in LAI measured, compared to the more uniform crop stand in the irrigated trials as reflected in the measured lower standard deviations (SD) between treatment replications in the field experiments (Figure 2a vs. Figure 2b). In the field experiments, SD in the measured LAI across the four treatment replications varied between 0.2 and 0.9 in the rainfed treatments and between 0.1 and 0.5 in the irrigated treatments. Under rainfed conditions, simulations had RRMSE of $21 \%$, ME of -0.1 , and RMSE of 0.6. Under irrigated conditions, the simulations resulted in RRMSE of $15 \%$, ME of -0.1 , and RMSE of 0.5 . The ME value of -0.1 for both rainfed and irrigated conditions denote a negative bias in the LAI simulation, but it is not severe enough to call for a recalibration of the model to remove the bias.

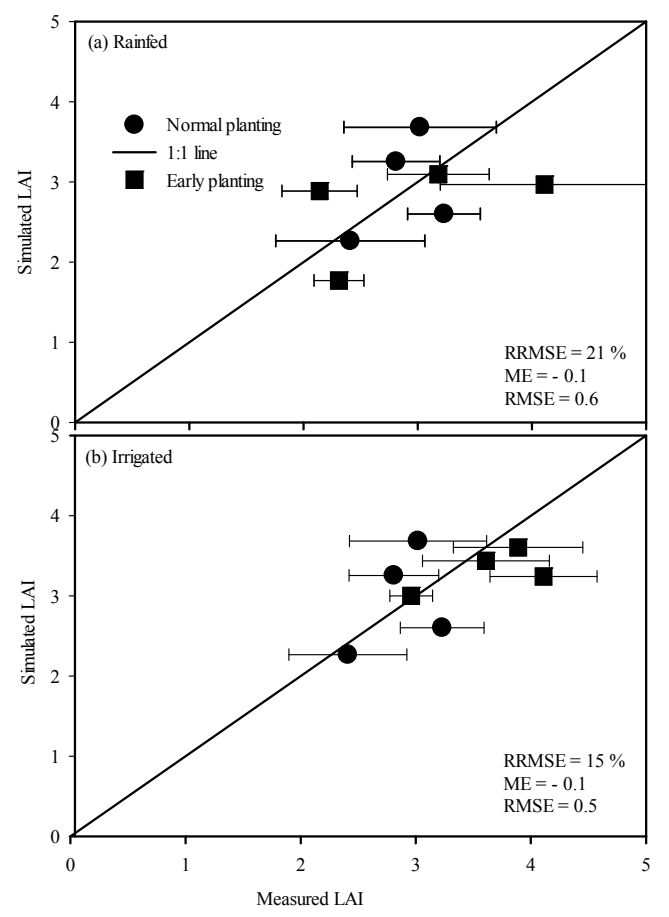

Figure 2. Measured and simulated cotton leaf area index (LAI) of normal and early plantings under rainfed (a) and irrigated (b) conditions during 2005-2008 (four data-points each per planting date) at Stoneville, MS. Error bars indicate one standard deviation (SD) from the mean of the measured LAI across the four treatment replications. 
Increased leaf area growth under irrigated conditions was well captured in the simulations. Across early and normal planting dates, LAI gain due to irrigation as measured in the field experiment was 0.35 , against 0.32 in the simulations. Under irrigated conditions, cotton planted on the normal planting dates produced higher LAI than the early-planted cotton by 0.78 , and this was well captured by the model with a simulated gain of 0.37 . Under rainfed conditions, similar LAI gain in the experiment was 0.07 and the model simulated a loss of -0.27 . This reverse in trend may have been an artifact of the larger plant-to-plant variability in the measured LAI under rainfed conditions.

Field-measured biomass under both irrigated and rainfed conditions showed considerable variation across experiment replications. Measured standard error in biomass across treatment replications in the field under rainfed conditions varied between 425 and $1185 \mathrm{~kg} \cdot \mathrm{ha}^{-1}$ and under irrigated conditions varied between 386 and $1250 \mathrm{~kg} \cdot \mathrm{ha}^{-1}$ (Figure 3). Simulated biomass showed good correspondence with the field-measured data. Under both early and normal planting conditions, biomass simulations under rainfed conditions had an RRMSE of $13 \%$, RMSE of $658 \mathrm{~kg} \cdot \mathrm{ha}^{-1}$, and ME of $-98 \mathrm{~kg} \cdot \mathrm{ha}^{-1}$, while simulations under irrigated conditions had an RRMSE of $11 \%$, RMSE of $610 \mathrm{~kg} \cdot \mathrm{ha}^{-1}$, and ME (bias) of $-223 \mathrm{~kg} \cdot \mathrm{ha}^{-1}$. A more negative ME score is seen for simulations of biomass under the irrigated conditions, compared to the rainfed conditons. In the field experiments, under both rainfed and irrigated conditions, the biomass of the early-planted cotton was substantially higher than that of the normal date planting. At the time of the biomass harvest, under rainfed conditions, the model simulated a biomass increase of $1578 \mathrm{~kg} \cdot \mathrm{ha}^{-1}$ against the field-measured increase of $2018 \mathrm{~kg} \cdot \mathrm{ha}^{-1}$. Under irrigated conditions, similar biomass gain measured was $2184 \mathrm{~kg} \cdot \mathrm{ha}^{-1}$, and in the simulations the gain was $3076 \mathrm{~kg} \cdot \mathrm{ha}^{-1}$.

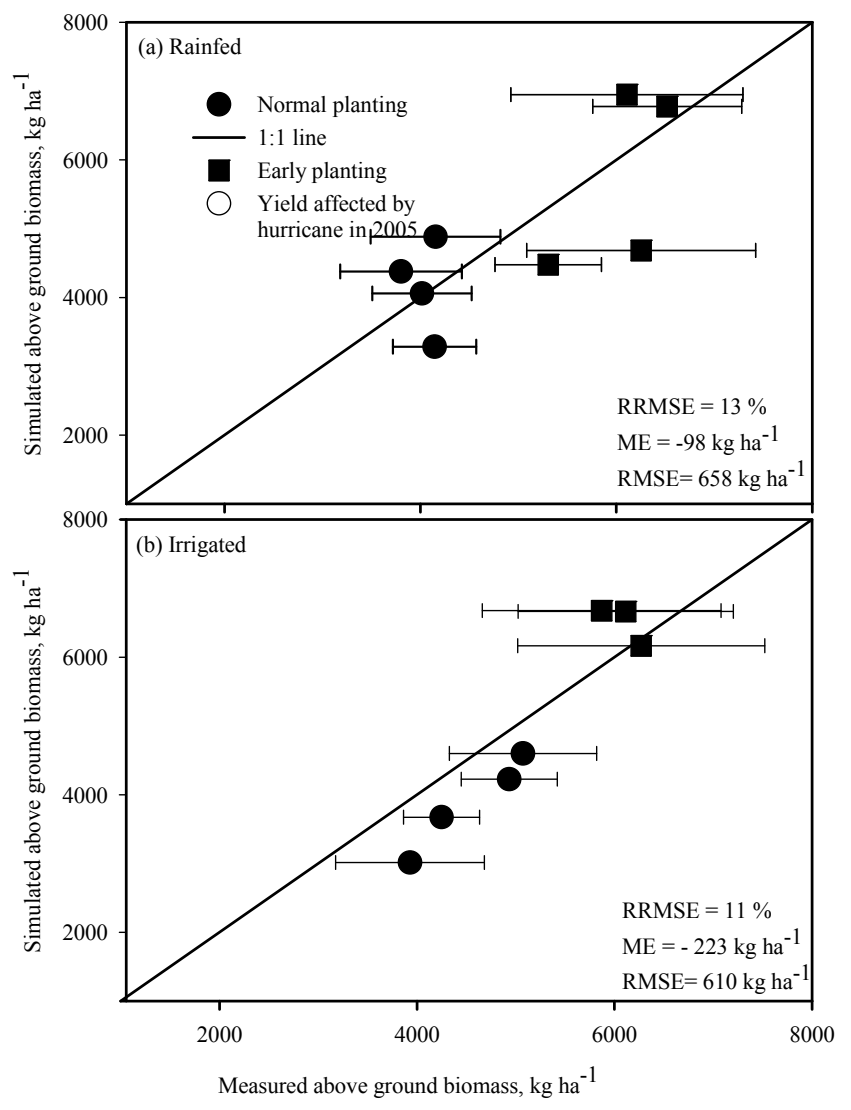

Figure 3. Measured and simulated aboveground cotton biomass yield of normal and early plantings under rainfed (a) and irrigated (b) conditions during 2005-2008 at Stoneville, MS. Error bars indicate one $\mathrm{SD}$ from the mean of the measured biomass across the four treatment replications. 
A high intensity hurricane named "Katrina" made landfall in the New Orleans coastal area on 25 August 2005, bringing heavy winds and rainfall over the MS Delta region that damaged the cotton crop in our experiments. This event occurred three weeks before harvest of the crop, and damage was reflected only in the measured seed cotton yield but not in the biomass and LAI, since they were measured before this damage occurred. As there was no way to account for and simulate hurricane-related crop losses in agricultural system models, the simulated seed cotton yield for 2005 were conspicuously greater than the measured data (Figure 4). The simulated data for 2005, therefore, were excluded from calculations of simulation error statistics of seed cotton yields. With this exception, seed cotton yields were simulated with accuracy levels comparable to those of LAI and biomass. Averaged across early and normal planting dates in the irrigated experiments, errors in seed cotton yield simulations were RRMSE $=14 \%$, RMSE $=333 \mathrm{~kg} \cdot \mathrm{ha}^{-1}$, and ME $=52 \mathrm{~kg} \cdot \mathrm{ha}^{-1}$. Similar errors resulted from the rainfed experiment simulations, with RRMSE $=8 \%$, RMSE $=278 \mathrm{~kg} \cdot \mathrm{ha}^{-1}$, and $\mathrm{ME}=81 \mathrm{~kg} \cdot \mathrm{ha}^{-1}$. The slight positive biases in the prediction of seed cotton yield under both rainfed and irrigated conditions were not severe enough to warrant any adjustments in the model calibration to remove those biases. Seed cotton yield gain with irrigations compared to the rainfed crop were also well simulated: across the two planting dates, the simulated yield gain was $1339 \mathrm{~kg} \cdot \mathrm{ha}^{-1}$ compared with the field-measured yield gain of $1369 \mathrm{~kg} \cdot \mathrm{ha}^{-1}$. The trend in yield reduction during the experimental period due to later planting, under both rainfed and irrigated conditions, were also well simulated. Under rainfed conditions, the simulated reduction was $6 \mathrm{~kg} \cdot \mathrm{ha}^{-1}$ while the measured yield reduction was $285 \mathrm{~kg} \cdot \mathrm{ha}^{-1}$, and under irrigated conditions, the simulated yield reduction was $136 \mathrm{~kg} \cdot \mathrm{ha}^{-1}$ compared with a measured yield reduction of $334 \mathrm{~kg} \cdot \mathrm{ha}^{-1}$.

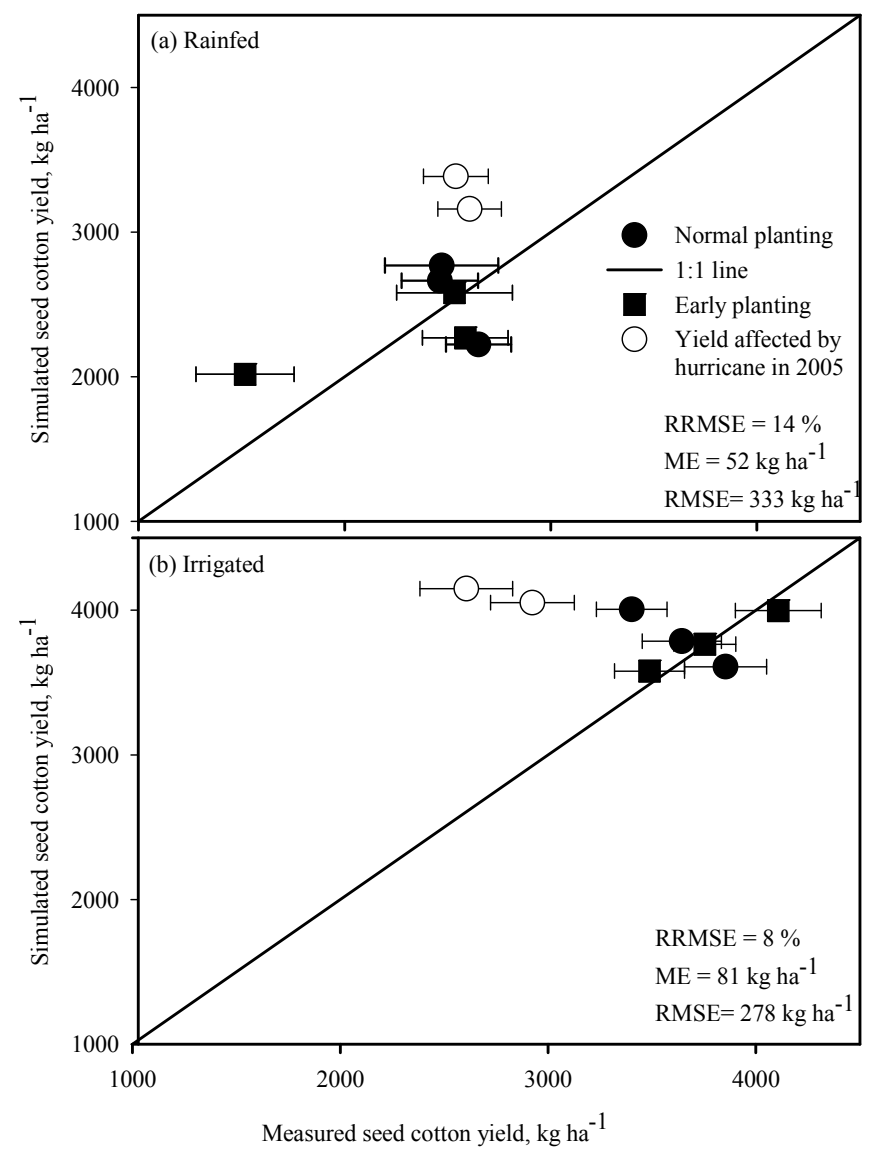

Figure 4. Measured and simulated seed cotton yield of normal and early plantings under rainfed (a) and irrigated (b) conditions during 2005-2008 at Stoneville, MS. Error bars indicate one SD from the mean of the measured yield across the four treatment replications. 


\subsection{Planting Windows}

The calibrated and tested models were integrated with weather data collected at the Stoneville location from 1960 to 2015 and simulated the crop under both irrigated and rainfed conditions, calculating average seed cotton yield for the 56 year period (Figure 5). In the simulations, fixed planting dates-2 April for an early planting and 2 May for a normal planting-were set under both rainfed and irrigated conditions. Planting density was set to $97,000 \mathrm{plant} \mathrm{ha}^{-1}, \mathrm{~N}$ applied at the rate of $110 \mathrm{~kg} \cdot \mathrm{N} \cdot \mathrm{ha}^{-1}$, and irrigations were conducted weekly to replenish $90 \%$ of the water in the soil that was lost to ET demands. Average seed cotton yield from the early planting date was higher than that of the normal planting date by $22 \mathrm{~kg} \cdot \mathrm{ha}^{-1}$. Average yield for the normal planting date was $2630 \mathrm{~kg} \cdot \mathrm{ha}^{-1}$ with an SD of $951 \mathrm{~kg} \cdot \mathrm{ha}^{-1}$ and for the early planting date was $2652 \mathrm{~kg} \cdot \mathrm{ha}^{-1}$ with an SD of $875 \mathrm{~kg} \cdot \mathrm{ha}^{-1}$. As observed during 2005-2008 experiments, late-July and August months are commonly characterized by maximum temperatures much above the upper threshold for cotton growth. These hot periods also normally coincide with low precipitation, leading to both water and temperature stresses that limit cotton growth and productivity (Boykin et al., 1995 [38]; Pettigrew, 2008 [39]; Scott et al., 1998 [40]; Kebede et al., 2014 [23]). There were also more late season insect infestation problems that we did not report in this paper (Pettigrew, 2008 [39]). The gain in yield due to the simulated early planting date was due to the ability of the plant to mature earlier than the normal planted crop, thereby avoiding later season drought and temperature stresses. Under rainfed conditions, in 15 out of 56 years, the seed cotton yields were below $2000 \mathrm{~kg} \cdot \mathrm{ha}^{-1}$, resulting in a $27 \%$ chance each year that seed cotton returns could be less than $2000 \mathrm{~kg} \cdot \mathrm{ha}^{-1}$. Similarly, a chance for yield to go below $1500 \mathrm{~kg} \cdot \mathrm{ha}^{-1}$ was $14 \%$, and below $1000 \mathrm{~kg} \cdot \mathrm{ha}^{-1}$ was $5 \%$. However, under irrigated conditions, simulations showed that yields in all crop seasons could be maintained near $4000 \mathrm{~kg} \cdot \mathrm{ha}^{-1}$.

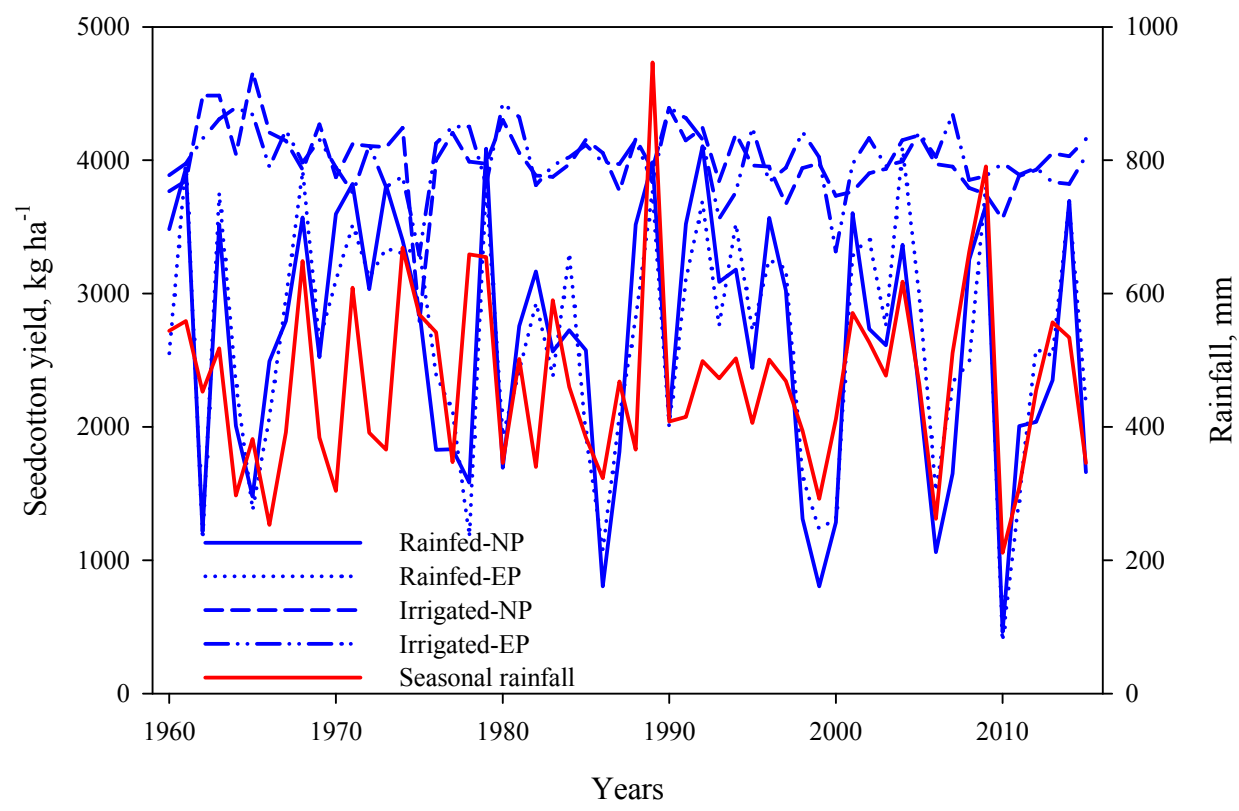

Figure 5. Simulated seed cotton yields of normal (NP) and early plantings (EP) under rainfed and irrigated conditions from 1960 to 2015 at Stoneville, MS. The EP was on 30 Mach and NP was on 2 May.

The gain in yield due to early planting in the case of the irrigated crop was less, as irrigations compensated for yield losses due to late-season water and temperature stress associated with late-season droughts (Figure 5). Average seed cotton yield for early planting was $4017 \mathrm{~kg} \cdot \mathrm{ha}^{-1}$ with an SD of $235 \mathrm{~kg} \cdot \mathrm{ha}^{-1}$, and for normal planting was $4009 \mathrm{~kg} \cdot \mathrm{ha}^{-1}$ with an SD of $266 \mathrm{~kg} \cdot \mathrm{ha}^{-1}$. The average irrigation water requirement for the early planting was $14 \mathrm{~cm}$, and for the normal planting 
was $18 \mathrm{~cm}$ (Figure 6), implying that irrigation water requirements increased for those planted later in the season.
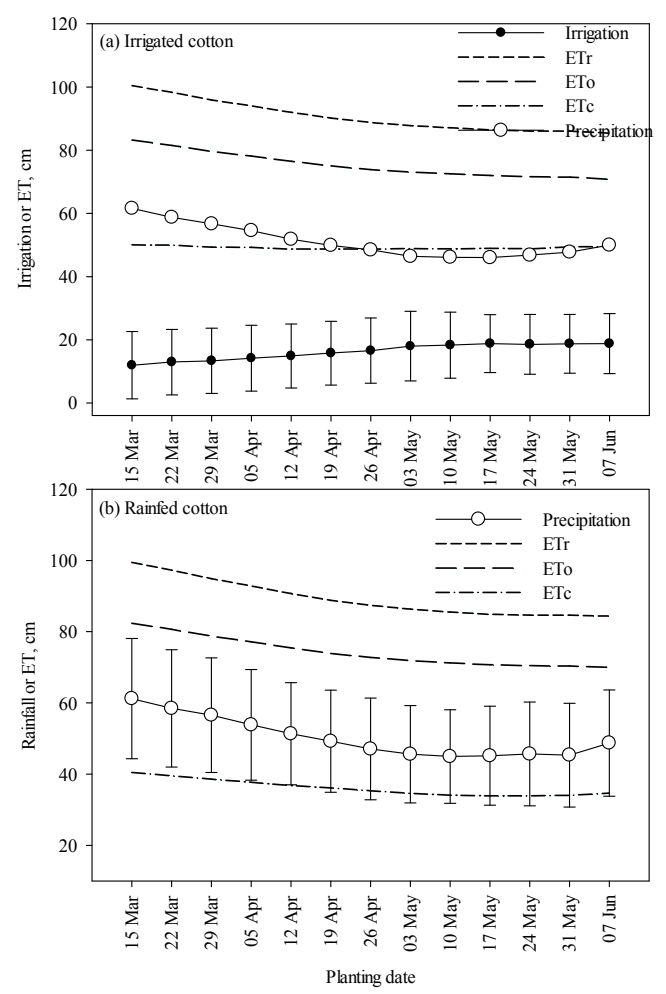

Figure 6. Long-term average (1960-2015) evapotranspiration for short grass (ETo) and alfalfa (ETr) reference crops and simulated crop evapotranspiration (ETc), irrigation, and precipitation during the cotton growth period occurred each year. The crops were planted at weekly intervals between March and June from 1960 to 2015 under rainfed (a) and irrigated (b) conditions at Stoneville, MS.

\subsection{Optimum Planting Windows (Climate-Optimized Planting Windows)}

Under irrigated conditions, planting in the first week of March produced an average seed cotton yield of $786 \mathrm{~kg} \cdot \mathrm{ha}^{-1}$ followed by 3001 and $3433 \mathrm{~kg} \cdot \mathrm{ha}^{-1}$ for 8 March and 15 March plantings, respectively (Figure 7). From 22 March planting and beyond, a much slower gain in yield-about $29 \mathrm{~kg} \cdot \mathrm{ha}^{-1}$ per week delay of planting until 24 May-was observed (Figure 7a). Probabilities of achieving seed cotton yields greater than $3000 \mathrm{~kg} \cdot \mathrm{ha}^{-1}$ were between $89 \%$ for the 24 March planting and $94 \%$ for the 24 May planting (Figure 7a).

Trends in long-term rainfed seed cotton yields with differing planting dates did not differ appreciably from the irrigated yields (Figure $7 \mathrm{~b}$ ). However, from 15 March planting and beyond, seed cotton yields showed a slight decline with every week delay in planting up to 31 May, and further delay resulted in a sharp decline in yield. The probability of achieving seed cotton yield greater than $2000 \mathrm{~kg} \cdot \mathrm{ha}^{-1}$ (median seed cotton yield under rainfed conditions) was 78\% for March 15 and 75\% for the 31 May plantings.

With the delay in plantings from the week of 15 March and beyond under irrigated conditions, there was only a slight gain in seed cotton yield (Figure $7 \mathrm{~b}$ ). The planting window remained equally productive until about 31 May, but further delay in plantings caused yields to decline faster with plantings on 1 June and beyond. The first week of June appears to be the latest for planting cotton and achieving reasonable yield returns. Based on a three-year study at Welsaco, Texas, Biggar et al. (1957 [41]) reported higher yields in mid-March plantings compared to mid-February planting due to higher soil and air temperatures as the season progressed. In a seven-year study with plantings between 20 April and 20 May in Lubbock, Texas, Bilbro and Ray (1969) [42] reported similar cotton 
yield returns and significant yield reduction with an additional 10 day planting delay after 20 May. These studies corroborate results from the simulated cotton yields. Cotton yields in the MS Delta region were reported to be influenced by the amount of sunlight received as the season progressed through the growing season, e.g., as the crop season progress from winter to summer months (Pettigrew and Meredith, 1994 [43]). Notwithstanding, Pettigrew (2002) [10] observed a 10\% improvement in irrigated seed cotton yields from first week of April plantings compared with first week of May plantings in three out of four years of field trials. The observed reverse trend in the remaining year was reported to be due to early season cold temperatures that stunted the early season plant growth. The CSM-CROPGRO-cotton model does not simulate the stunting effects of low temperatures on early season cotton plants, therefore, this effect was not accounted for in the simulations. However, from the analysis of the temperature data collected at the location during 1960-2016, we concluded that the frost observed in 1997 was a rare event that does not often occur in the humid subtropical climate of the MS Delta.

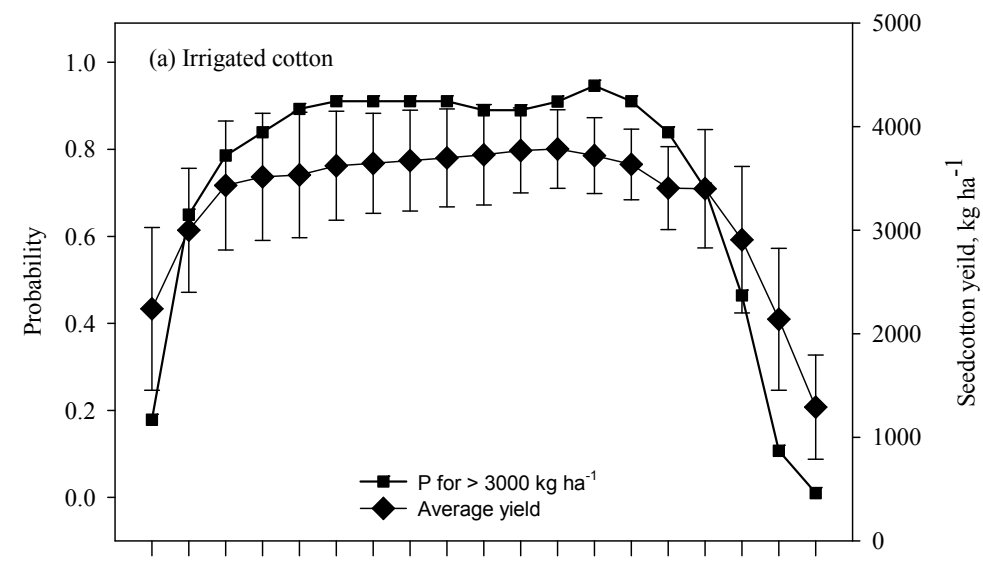

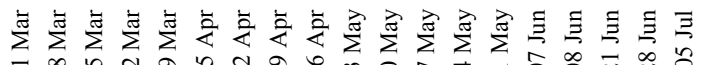

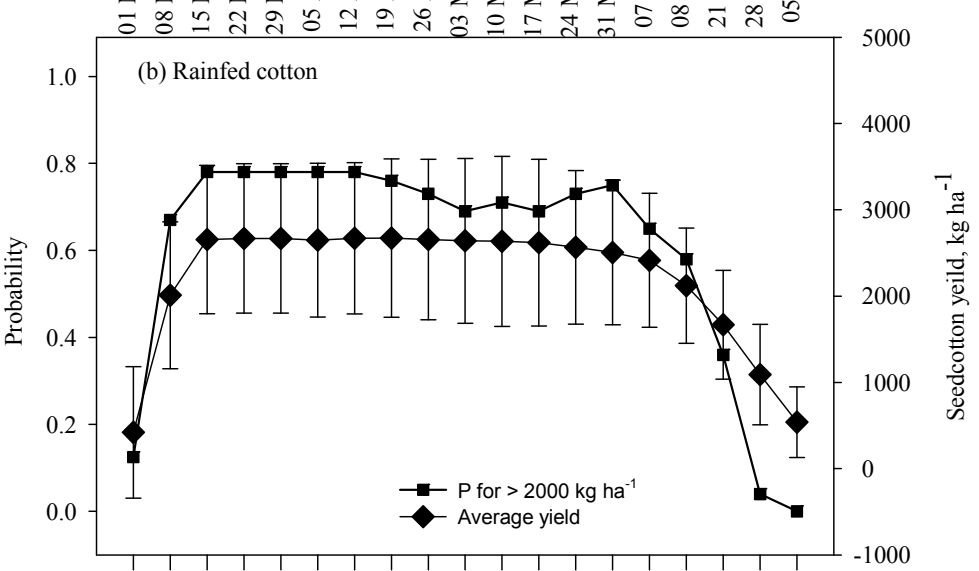

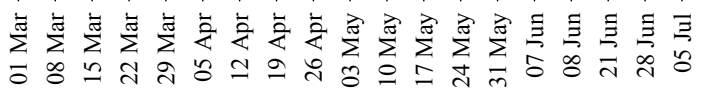

Planting Day

Figure 7. Mean simulated irrigated (a) and rainfed (b) seed cotton yields and the probabilities of achieving breakeven seed cotton yields $\left(2000 \mathrm{~kg} \cdot \mathrm{ha}^{-1}\right.$ for rainfed and $3000 \mathrm{~kg} \cdot \mathrm{ha}^{-1}$ for irrigated conditions) at Stoneville, MS. The crops were planted at weekly intervals from 1 March through 5 July.

\subsection{Irrigation}

Long-term (1960-2015) average rainfall received during the simulated cotton growth periods for plantings from 15 March to 7 June varied between $46 \mathrm{~cm}(\mathrm{SD}=13 \mathrm{~cm})$ and $62 \mathrm{~cm}(\mathrm{SD}=17 \mathrm{~cm})$ (Figure $6 a, b$ ). The rainfall capture during the crop growth period was highest for the 15 March planting 
$(62 \mathrm{~cm})$ and declined with the delay in planting, in general, with a minimum rainfall capture observed for the 17 May planting $(46 \mathrm{~cm})$. On average, during 1960-2015, $51 \mathrm{~cm}(\mathrm{SD}=14 \mathrm{~cm})$ of rainfall was received, and average $15 \mathrm{~cm}(\mathrm{SD}=10 \mathrm{~cm})$ of water was needed per season for irrigating the crop. Average computed long-term short grass reference-crop evapotranspiration (ETo, Allen et al., 1998 [44]), afalfa reference-crop evapotranspiration (ETr, ASCE-EWRI, 2005 [45], and model-simulated actual crop evapotranspiration, ETc, for the crop growth period were 74, 89, and $48 \mathrm{~cm}$, respectively. Average simulated ETc under rainfed conditions was $36 \mathrm{~cm}$, resulting in a deficiency of $12 \mathrm{~cm}$ of ETc compared to the irrigated crop, which accounted for an average seed cotton yield loss of $808 \mathrm{~kg} \cdot \mathrm{ha}^{-1}$ (average simulated yield under irrigated conditions was $3051 \mathrm{~kg} \cdot \mathrm{ha}^{-1}$ and simulated yield under rainfed conditions was $2243 \mathrm{~kg} \cdot \mathrm{ha}^{-1}$ ).

\section{Conclusions}

Based on field experiments conducted at Stoneville in the MS Delta region during 2005-2008, the CSM-CROPGRO-cotton version 4.6 module within the RZWQM2 model was calibrated and tested for simulation of seed cotton production under both irrigated and rainfed conditions and two planting dates, early season and normal season. By integrating the model with long-term (1960-2015) weather data at the location, long-term, climate optimized, planting decision support information for determining planting windows for seed cotton production under both rainfed and irrigated conditions were developed. Results of these investigations revealed that under rainfed conditions, every crop season, there is a $27 \%$ chance for yield returns below $2000 \mathrm{~kg} \cdot \mathrm{ha}^{-1}$, a $14 \%$ chance below $1500 \mathrm{~kg} \cdot \mathrm{ha}^{-1}$, and a $5 \%$ chance below $1000 \mathrm{~kg} \cdot \mathrm{ha}^{-1}$. In the long-term, irrigated cotton produced substantially higher seed cotton yield than rainfed cotton, with an average irrigation requirement of $15 \mathrm{~cm}$ with an SD of $10 \mathrm{~cm}$. While rainfed cotton yields declined from later plantings, irrigated cotton benefitted. Mid-March to the end of May under rainfed conditions, and end of April to the end of May under irrigated conditions, were long-term climate-optimized planting windows for the best cotton production in the region. The planting date decision support information developed in this study will be useful to cotton farmers in the region to make decisions on when to plant for best yield returns. However, while the information developed in this study may not be readily applicable in other soils in the MS Delta region, the methodology developed can be utilized for developing similar planting date decision support information in those places.

Acknowledgments: We thank the Delta Agricultural Weather Center, Delta Research and Extension Center, Mississippi State University, USA for the long-term weather data used in this study.

Author Contributions: Saseendran Anapalli conceived, performed data analysis and interpretation and wrote the manuscript. William Pettigrew was responsible for the field experiments, also contributed to the design of the manuscript and interpretation of the results. Krishna Reddy contributed to the design of the manuscript, analysis, and interpretation of the data. Liwang Ma was responsible for linking the RZWQM2 soil module with the CSM-CROPGRO v4.6 crop model code and testing the linked model for accuracy in simulations. Daniel Fisher contributed to the analysis and interpretation of the results. Ruixiu Sui also contributed to the analysis and interpretation of the results.

Conflicts of Interest: The authors declare no conflict of interest.

\section{References}

1. Riley, J.A. Soil Temperatures and Cotton Planting in the Mid-South; State College: Pennsylvania, PA, USA; Mississippi State University: Starkville, MS, USA; Agricultural Experiment Station: Fayetteville, AR, USA, 1964; p. 11.

2. Delta Research and Extension Center. Available online: http://www.deltaweather.msstate.edu/ (accessed on 26 September 2016).

3. Bridge, R.R.; Meredith, W.R.; Chism, J.F. Influence of cotton planting dates studied. Miss. Farm Res. 1971, 34, 4-6.

4. Pettigrew, W.T.; Dowd, M.K. Varying planting dates or irrigation regimes alters cottonseed composition. Crop Sci. 2011, 51, 2155-2164. [CrossRef] 
5. Wrather, J.A.; Phipps, B.J.; Stevens, W.E.; Phillips, A.S.; Vories, E.D. Cotton planting date and plant population effects on yield and fiber quality in the Mississippi Delta. J. Cotton Sci. 2008, 12, 1-7.

6. Adams, B.; Catchot, A.; Gore, J.; Cook, D.; Musser, F.; Dodds, D. Impact of planting date and varietal maturity on tarnished plant bug (Hemiptera: Miridae) in cotton. Cotton J. Econ. Entomol. 2013, 106, 2378-2383. [CrossRef] [PubMed]

7. Pettigrew, W.T.; Molin, W.T.; Stetina, S.R. Impact of varying planting dates and tillage systems on cotton growth and lint yield production. Agron. J. 2009, 101, 1131-1138. [CrossRef]

8. Pettigrew, W.T.; Meredith, W.R., Jr. Seed quality and planting date eff ects on cotton lint yield, yield components, and fiber quality. J. Cotton Sci. 2009, 13, 37-47.

9. Berry, N.B.O.; Faircloth, J.C.; Edmisten, K.L.; Collins, G.D.; Stewart, A.M.; Abaye, A.O.; Herbert, D.A., Jr.; Haygood, R.A. Plant population and planting date effects on cotton (Gossypium hirsutum L.) Growth and Yield. J. Cotton Sci. 2008, 12, 178-187.

10. Pettigrew, W.T. Improved yield potential with an early planting cotton production system. Agron. J. 2002, 94, 997-1003. [CrossRef]

11. Pettigrew, W.T. Impact of varying planting dates and irrigation regimes on cotton growth and lint yield production. Agron. J. 2010, 102, 1379-1387. [CrossRef]

12. Pettigrew, W.T.; Dowd, M.K. Interactions between irrigation regimes and varieties result in altered cottonseed composition. J. Cotton Sci. 2010, 201, 16-42.

13. Hoogenboom, G.; Jones, J.W.; Boote, K.J. A decision support system for prediction of crop yield, evapotranspiration, and irrigation management. In Proceedings of the 1991 National Conference, Honolulu, HI, USA, 22-26 July 1991; pp. 198-204.

14. Ahuja, L.R.; Rojas, K.W.; Hanson, J.D.; Shafer, M.J.; Ma, L. Root Zone Water Quality Model. Modeling Management Effects on Water Quality and Crop Production; Water Resources Publications, LLC: Highlands Ranch, CO, USA, 2000.

15. Ahuja, L.R.; Ma, L.; Lascano, R.J.; Saseendran, S.A.; Fang, Q.X.; Nielsen, D.C.; Colaizzi, P.D. Practical Applications of Agricultural System Models to Optimize the Use of Limited Water. Available online: https:// portal.sciencesocieties.org/resources/files/Downloads/pdf/B40818.pdf (accessed on 26 September 2016).

16. Ahuja, L.R.; Ma, L.; Fang, Q.X.; Saseendran, S.A.; Islam, A.; Malone, R.W. Computer modeling: Applications to environment and food security. In Encyclopedia of Agriculture and Food Systems; van Alfen, N., Ed.; Elsevier Publishers: New York, NY, USA, 2014; pp. 337-358.

17. Saseendran, S.A.; Ma, L.; Nielsen, D.C.; Vigil, M.F.; Ahuja, L.R. Simulating planting date effects on corn production using RZWQM and CERES-Maize. Agron. J. 2005, 97, 58-71. [CrossRef]

18. Garcia y Garcia, A.; Persson, T.; Paz, J.O.; Fraisse, C.; Hoogenboom, G. ENSO-based climate variability affects water use efficiency of rainfed cotton grown in the southeastern USA. Agric. Ecosyst. Environ. 2010, 139, 629-635. [CrossRef]

19. Paz, J.O.; Woli, P.; Garcia, A.G.; Hoogenboom, G. Cotton yields as influenced by ENSO at different planting dates and spatial aggregation levels. Agric. Syst. 2012, 111, 42-52. [CrossRef]

20. Jones, J.W.; Hoogenboom, G.; Porter, C.H.; Boote, K.J.; Batchelor, W.D.; Hunt, L.A.; Wilkens, P.W.; Singh, U.; Gijsman, A.J.; Ritchie, J.T. DSSAT Cropping System Model. Eur. J. Agron. 2003, 18, 235-265. [CrossRef]

21. Guerra, L.C.; Garcia y Garcia, A.; Hook, J.E.; Harrison, K.A.; Thomas, D.L.; Stooksbury, D.E.; Hoogenboom, G. Irrigation water use estimates based on crop simulation models and kriging. Agric. Water Manag. 2007, 89, 199-207. [CrossRef]

22. Boote, K.J.; Pickering, N.B. Modeling photosynthesis of row crop canopies. Hort. Sci. 1994, 29, $1423-1434$.

23. Kebede, H.; Fisher, D.K.; Sui, R.; Reddy, K.N. Irrigation methods and scheduling in the delta region of Mississippi: Current status and strategies to improve irrigation efficiency. Am. J. Plant Sci. 2014, 5, 2917-2928. [CrossRef]

24. Clark, B.R.; Hart, R.M.; Gurdak, J.J. Groundwater Availability of the Mississippi Embayment: U.S. Geological Survey Professional Paper; BiblioGov: Columbus, OH, USA, 2011.

25. Ma, L.; Hoogenboom, G.; Saseendran, S.A.; Bartling, P.N.S.; Ahuja, L.R.; Green, T.R. Estimates of soil hydraulic properties and root growth factor on soil water balance and crop production. Agron. J. 2009, 101, 572-583. [CrossRef]

26. Ma, L.; Nielsen, D.C.; Ahuja, L.R.; Malone, R.W.; Saseendran, S.A.; Rojas, K.W.; Hanson, J.D.; Benjamin, J.G. Evaluation of RZWQM under varying irrigation levels in eastern Colorado. Trans. ASAE 2003, 46, 39-49. 
27. Saseendran, S.A.; Ahuja, L.R.; Nielsen, D.C.; Trout, T.J.; Ma, L. Use of crop simulation models to evaluate limited irrigation management options for corn in a semiarid environment. Water Rescour. Res. 2008. [CrossRef]

28. Saseendran, S.A.; Nielsen, D.C.; Lyon, D.J.; Ma, L.; Felter, D.G.; Baltensperger, D.D.; Hoogenboom, G.; Ahuja, L.R. Modeling responses of dryland spring triticale, proso millet and foxtail millet to initial soil water in the High Plains. Field Crops Res. 2009, 10, 48-63. [CrossRef]

29. Saseendran, S.A.; Ahuja, L.R.; Ma, L.; Trout, T.J.; McMaster, G.S.; Andales, A.A.; Chavez, J.; Ham, J. Enhancing RZWQM2 for water stress responses of corn (Zea mays. L.). Agron. J. 2014, 106, 81-94. [CrossRef]

30. Nimah, M.N.; Hanks, R.J. Model for estimating soil water, plant and atmospheric inter relations: I. description and sensitivity. Proc. Soil Sci. Soc. Am. 1973, 37, 522-527. [CrossRef]

31. Ma, L.; Hoogenboom, G.; Ahuja, L.R.; Ascough, J.C., II; Saseendran, S.A. Evaluation of the RZWQM-CERES-Maize hybrid model for maize production. Agric. Syst. 2006, 87, 274-295. [CrossRef]

32. Hoogenboom, G.; Jones, J.W.; Wilkens, P.W.; Porter, C.H.; Boote, K.J.; Hunt, L.A.; Singh, U.; Lizaso, J.L.; White, J.W.; Uryasev, O.; et al. Decision Support System for Agrotechnology Transfer (DSSAT) Version 4.5 [CD-ROM]; University of Hawaii: Honolulu, HI, USA, 2012.

33. United States Department of Agriculture-Agricultural Research Service. Available online: http:/ /arsagsoftware.ars.usda.gov/DownloadSoftware.aspx (accessed on 26 September 2016).

34. Shuttleworth, W.J.; Wallace, J.S. Evaporation from sparse crops-an energy combination theory. Q. J. R. Meteorol. Soc. 1985, 111, 839-855. [CrossRef]

35. Green, W.H.; Ampt, G.A. Studies on soil physics. 1. Flow of air and water through soils. J. Agric. Sci. 1911, 4, 1-24.

36. Ma, L.; Ahuja, L.R.; Saseendran, S.A.; Malone, R.W.; Green, T.R.; Nolan, B.T.; Bartling, P.N.S.; Flerchinger, G.N.; Boote, K.J.; Hoogenboom, G. A Protocol for Parameterization and Calibration of RZWQM2 in Field Research. In Methods of Introducing System Models into Agricultural Research; Ahuja, L.R., Ma, L., Eds.; Advances in Agricultural Systems Modeling Series 2; American Society of Agronomy: Madison, WI, USA, 2011; pp. 1-64.

37. Brooks, R.H.; Corey, A.T. Hydraulic Properties of Porous Media; Colorado State University: Fort Collins, CO, USA, 1964; pp. 1-15.

38. Boykin, D.L.; Carle, R.R.; Ranney, C.D.; Shanklin, R. Weather Data Summary for 1964-1993 at Stoneville, Mississippi; Mississippi Agriculture and Forestry Experiment Station: Pontotoc, MS, USA, 1995; pp. 1-28.

39. Pettigrew, W.T. The effect of higher temperatures on cotton lint yield production and fiber quality. Crop Sci. 2008, 48, 278-285. [CrossRef]

40. Scott, H.D.; Feguson, J.A.; Hanson, L.; Fugitt, T.; Smith, E. Agricultural Water Management in the Mississppi Region of Arkansas; Arkansas Agricultural Experiment Station: Fayetteville, AR, USA, 1998.

41. Biggar, J.W.; Bloodworth, M.E.; Burleson, C.A. Effect of Precipitation Differentials and Plantings Date on the Growth, Yield, and Fiber Characteristics of Cotton in the Lower Rio Grande Valley; Texas Agriculture Experiment Station: Brazos, TX, USA, 1957.

42. Bilbro, J.D.; Ray, L.L. Differential Effects of Planting Date on the Performance of Cotton Varieties on the High Plains of Texas, 1960-1965; Texas Agriculture Experiment Station: Brazos, TX, USA, 1969; pp. 1-7.

43. Pettigrew, W.T.; Meredith, M.R., Jr. Leaf gas exchange parameters vary among cotton genotypes. Crop Sci. 1994, 34, 700-705. [CrossRef]

44. Allen, R.G.; Pereira, L.S.; Raes, D.; Smith, M. Crop Evapotranspiration: Guidelines for Computing Crop Water Requirement; United Nations Food and Agriculture Organization, Irrigation and Drainage: Rome, Italy, 1998.

45. ASCE-EWRI. The ASCE Standardized Reference Evapotranspiration Equation. In Standardization of Reference Evapotranspiration Task Committee Final Report; Allen, R.G., Walter, I.A., Elliot, R.L., Howell, T.A., Itenfisu, D., Jensen, M.E., Snyder, R.L., Eds.; Environmental and Water Resources Institute: Reston, VA, USA; American Society of Civil Engineers: Reston, VA, USA, 2005; pp. 1-11.

(C) 2016 by the authors; licensee MDPI, Basel, Switzerland. This article is an open access article distributed under the terms and conditions of the Creative Commons Attribution (CC-BY) license (http:/ / creativecommons.org/licenses/by/4.0/). 